\title{
Wellcome wages battle to house companies next to genome labs
}

[CAMBRIDGE, ENGLAND] Britain's Wellcome Trust is locked in a bitter battle with local

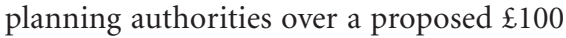
million (US\$162 million) commercial extension to its Genome Campus in Hinxton, Cambridgeshire.

At a public inquiry last week, the local authority confirmed its opposition to the extension, which the trust wants to provide space for small biotechnology companies involved in exploiting the campus's work on genome sequencing.

The trust argues that it is essential for these companies to be next to the campus to maximize their chance of success. But the local authority says the development would contravene government guidelines on the use of agricultural land and transport policy.

The final decision on the plan now rests with the deputy prime minister and environment secretary, John Prescott. His judgement will reflect the extent to which the government's pledge to support knowledgebased businesses is compatible with its desires to protect the countryside and limit the use of cars.

The trust wants to provide space for up to 600 people in genome-based businesses within walking distance of its Hinxton campus, 10 miles from the city of Cambridge and next to the villages of Hinxton and Ickleton.

It claims that, without the 40,000 square metres of extra space, Britain will lose a valuable opportunity to commercialize

\section{Local residents unimpressed by growth plan}

[CAMBRIDGE, ENGLAND] The Wellcome Trust's proposed Genome Campus extension is being opposed by the residents of the nearby villages of Hinxton and Ickleton - combined population of fewer than 1,000 - who see the plan as the thin end of a wedge.

Part of their opposition stems from a fear that the trust is planning an entire 'genome village', which they believe will destroy their rural way of life. Some also attack the glossy corporate image that the trust has developed, arguing that, although it may be successful in influencing government, it is out of touch with local feeling.

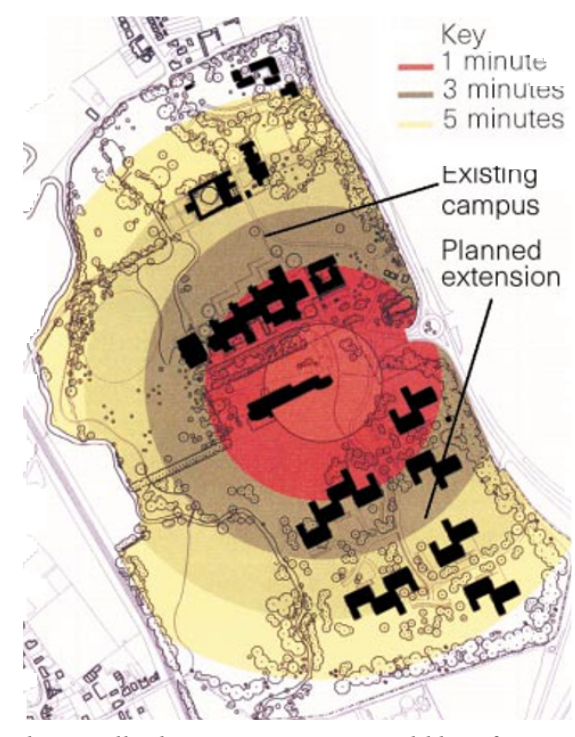

Short walk: the new extension would be a few minutes from Hinxton's Genome Campus (top).

research spinning out of the genome campus's three laboratories: the Sanger Centre for gene sequencing, the European Bioinformatics Institute, and the Human Genome Mapping Project Resource Centre.

But South Cambridgeshire District Council says that space for 'spin-out' companies already exists on the district's many science parks. And it argues that further construction on the Hinxton site contravenes government policies to restrict new building on agricultural land and in places that are not adequately served by public transport.

The inquiry was chaired by a government planning inspector, who will advise Prescott of his decision in the coming weeks. The inspector has already advised against the extension once. But, given the potential significance of the scheme to the UK economy, Prescott gave Wellcome a second chance.

The trust was asked to justify why it needs the extra space, and to explain how it intends to match the council's green transport target of a 50 per cent reduction in car journeys when the extension opens in 2001.

Prescott has in principle accepted the need for a smaller 'innovation centre' - a building housing companies up to three years old. But the trust wants additional space to house 'nursery'-stage companies up to six years old that have outgrown the centre. It estimates that demand for premises will come from 28 companies a year during the first two years.

During the public inquiry's three days, the trust relied heavily on endorsements for its plan from leading bioscientists with experience of research commercialization. It also unveiled its 'green travel plan', which includes measures to encourage employee car sharing, extra buses between the campus and nearby cities and towns, and on-site parking restrictions.

The council reluctantly acknowledged that these measures could contribute substantially towards meeting its green travel targets. But it refused to concede the Wellcome Trust's main contention that businesses that rely on results from the Human Genome Project need to be within walking distance of the Hinxton campus.

Michael Morgan, chief executive of the genome campus, says there are two main ideas behind the plan to locate biotech companies alongside the research workers. One is to provide scientists and entrepreneurs with formal and informal meeting places, such as shared conference and coffee rooms, sports and social facilities, to help generate ideas. The second is to make it easier for scientists who set up companies to maintain links with the laboratories in which they had worked.

But Simon Bird, the barrister for South Cambridgeshire District Council, pointed out that the trust was unable to produce substantial quantitative evidence that spin-out companies within walking distance of research laboratories are more likely to succeed than those located within driving distance. This point was also made by witnesses 


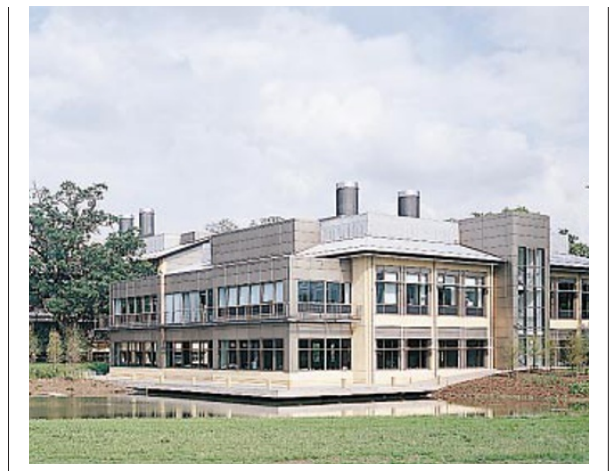

Existing buildings on the Hinxton campus, home of Britain's role in the Human Genome Project.

who supported the council's view. One such witness was Roger Quince, managing director of a nearby science park, Granta Park, and a founder of the technology management consultancy Segal, Quince, Wicksteed. He said the plan presupposes that research at the campus will lead directly to commercialization - the so-called 'linear model'.

Quince pointed out that individuals who were located elsewhere, such as at research departments at the University of Cambridge, hospitals and other businesses, were equally likely to contribute to the development of drugs from genomics.

Despite the absence of quantitative data, the trust had obtained letters of support from senior scientists representing science parks in Israel and the United States, as well as from major pharmaceutical companies.

Support also came from PPL Therapeutics, which in 1992 moved from premises at the University of Edinburgh to offices within 200 metres of the Roslin Institute, home of Dolly, the first cloned sheep. "I am convinced that our extremely successful participation, in what turned out to be a major scientific breakthrough, would not have occurred had we still been five miles down the road in Edinburgh University," wrote Alan Coleman, PPL's research director.

EhsanMasood

\section{New Howard Hughes head seeks bioinformatics boost}

[wASHINGTON] The Howard Hughes Medical Institute last week named biochemist Thomas Cech as its next president.

Cech won the Nobel Prize in Chemistry in 1989 for his work on the biocatalytic function of ribonucleic acid. He intends to maintain his laboratory at the University of Colorado at Boulder while running the United States' largest research philanthropy from its headquarters at Chevy Chase, Maryland.

"My two great passions have been biomedical research and science education," Cech says. "This is an opportunity to get involved in these issues at the highest level."

The 51-year-old scientist hopes to see Hughes taking a more active role in applying information technology to biology. "Computing is revolutionizing biology, and we could be at the forefront of bioinformatics," he says. "The institute could support investments in bioinformatics and, for example, set up regional centres" for computing.

Hughes currently spends most of its $\$ 420$ million science programme on directly supporting 318 US investigators, among them many of the country's most accomplished life scientists, including Cech. It also spends $\$ 100$ million each year on a grants programme that supports the reform of lifescience teaching at US universities, as well as researchers outside the United States.

Cech, who has always taught chemistry to first-year students at his own university, is very enthusiastic about the university teaching programme. "It's a real American success story," he says. "Everywhere I go, institutes have been using this money to redefine the way they educate science students."

He seems less sure about the international programmes that support scientists in

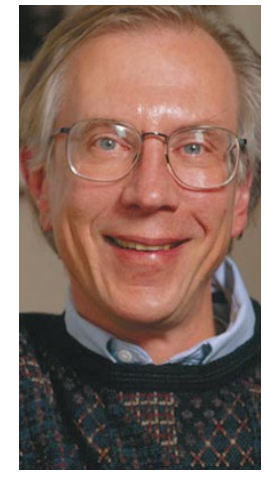

Cech: a passion for science education. Trust, the only medical research philanthropy of comparable size, Cech doesn't expect to follow its example by influencing government research policy.

"Lobbying the government is not on my list of activities," he says. Hughes may, however, raise its profile by becoming more involved in public discussion of the ethical, legal and other issues surrounding science.

The Howard Hughes Medical Institute was set up by the billionaire aviator as a tax dodge in 1953, but was reconstituted after his death. Independent trustees gained control in 1984, sold its main asset, Hughes Aircraft, to General Motors, and reached an agreement with tax authorities that requires it to spend at least 3.5 per cent of its vast endowment on medical research.

The stock-market boom has taken the value of that endowment to more than \$11 billion. Cech will probably become the world's best-paid science administrator next January. His predecessor Purnell Choppin, president since 1987, earned more than $\$ 600,000$ a year.

Colin Macilwain

\section{Scientists welcome Prodi as European Commission president}

[MUNICH] Last week's appointment of former Italian prime minister Romano Prodi as president of the European Commission, following the resignation of his predecessor Jacques Santer, could be good news for Europe's scientific community.

Prodi, a professor of economics at the University of Bologna, is a firm believer in the importance of science to a strong, stable economy (see Nature 375, 620; 1995). As prime minister he oversaw the start of a major review of Italy's science institutions.

Glauco Tocchini-Valentini, director of the Italian National Research Council's Institute of Cell Biology at Monterotondo, says Prodi has always been very sensitive to science.

Enric Banda, general secretary of the
European Science Foundation, calls Prodi "a federalist who believes in promoting cooperation between institutions". He believes that Prodi will be sympathetic to the concept of significant levels of basic research being carried out at European level.

"Fundamental research is certainly seen as a federal issue in the United States," Banda points out. In contrast, basic research has had to fight to maintain its small presence in the European Union's fifth Framework programme (FP5), as it is considered primarily the responsibility of individual member states.

"I'm sure that his appointment as head of the commission must be good for science in the medium term - even if science becomes temporarily swallowed up by other political priorities," says Banda. Such was the fate of the Italian science review, which is only now approaching completion.

Prodi's choice of research commissioner, which should become clear by early summer, will also be important. But as he puts together his new commission over the next month, European scientists need not fear that FP5 project funding will be delayed.

The research commission, foreseeing the possible departure of the commissioners who resigned en bloc following a critical report - ensured that any critical decisions on individual FP5 programmes were taken by early March. Calls for proposals for each of them have now been issued. Alison Abbott 